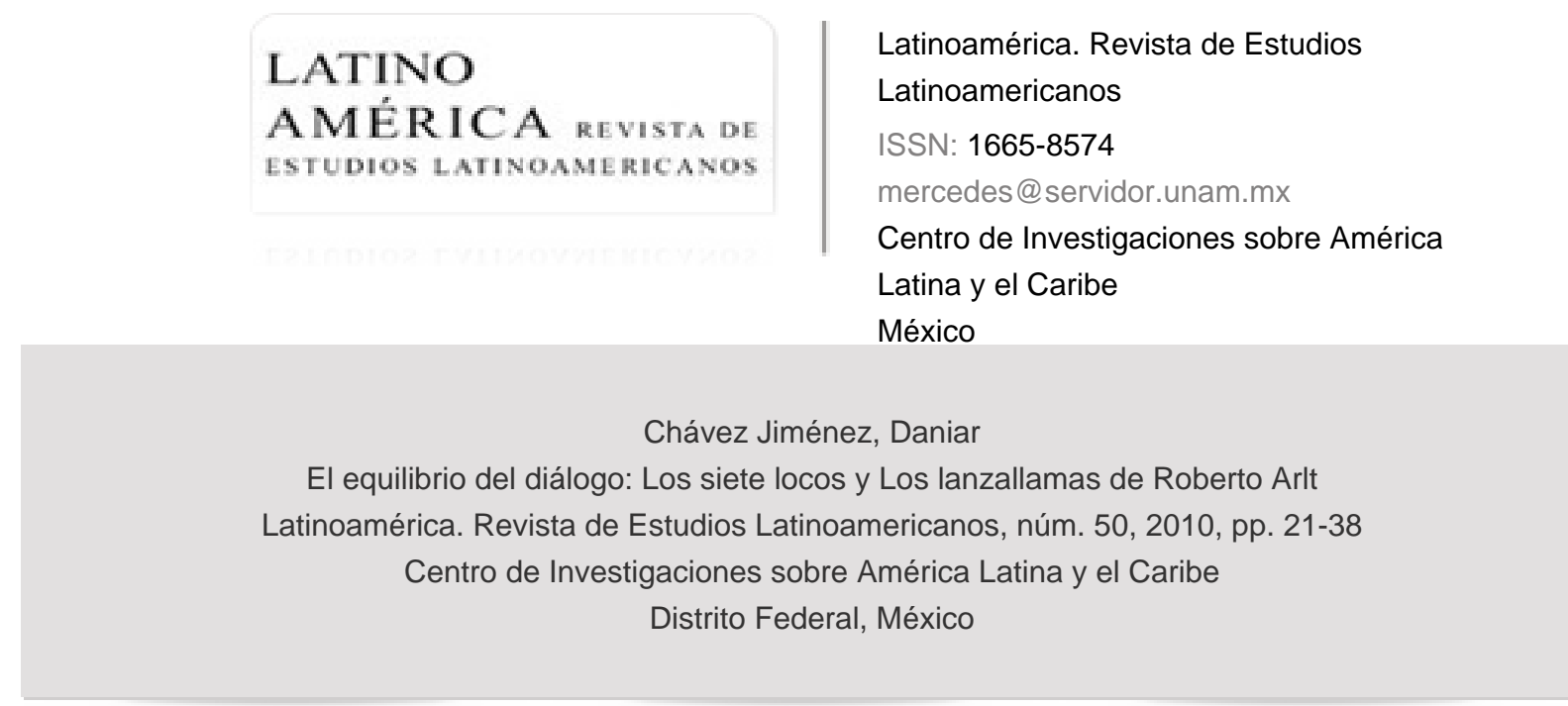

Disponible en: http://www.redalyc.org/articulo.oa?id=64014997003

- Cómo citar el artículo

- Número completo

- Más información del artículo

- Página de la revista en redalyc.org

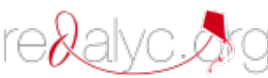

Sistema de Información Científica

Red de Revistas Científicas de América Latina, el Caribe, España y Portugal Proyecto académico sin fines de lucro, desarrollado bajo la iniciativa de acceso abierto 


\section{El equilibrio del diálogo: \\ Los siete locos y Los lanzallamas de Roberto Arlt}

Daniar Chávez Jiménez"

REsUMEN: El siguiente estudio realiza un recorrido a través de dos de las obras del autor argentino Roberto Arlt, Los siete locos y Los lanzallamas; el artículo intenta llamar la atención sobre las múltiples influencias filosóticas e ideológicas que la literatura arltiana ha obtenido de los ambientes intelectuales europeos del siglo xix y principios del xx, y que a través de diferentes lecturas y ciertos procesos culturales y sociales actuales al autor, llegan al imaginario narrativo de estos textos. Con base en la propuesta analíitca de Arthur Herman, en su obra La idea de decadencia en la historia de Occidente, se establece un diálogo entre el texto y su contexto.

Palabras Clave: Literaturas de vanguardia, Dialogismo, Filosofía e historia del pensamiento, Decadentismo, Pesimismo cultural.

ABSTRACT: This essay is an analysis that focuses around two of de main works of Argentinian author Roberto Arlt, Los Siete Locos and Los Lanzallamas. The essay emphasizes the multiple philosophical and ideological influences the European intellectual environments of the XIX and XX centuries have had over Arltian literature. It also focuses in the way these influences have reached - through different readings and specific cultural and social processes — the cultural narrative imaginary of these texts. Based on the analytic proposal of Arthur Herman in his La idea de decadencia en la historia de Occidente, the essay establishes a dialogue between text and context.

Key woRDS: Vanguard Literatures, Dialogism, Philosophy and the History of Thought, Decadentism, Cultural Pessimism.

"Posgrado Facultad de Filosofía y Letras, unam (daniarc@yahoo.com). 
Leerlo va a ser siempre un oficio incierto. Labor de quien acompaña la aventura arltiana con la incesante pregunta: ¿qué babrá querido decir?

Horacio González

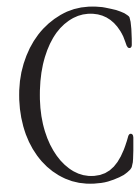

uando uno se enfrenta por primera vez a Los siete locos (1929) y a Los lanzallamas $(1930)^{1}$ una sensación de insólita pesadumbre lo envuelve. Sentimiento complejo, extrapolado, contradictorio, que lo deja sin aliento alguno y, sin duda, también sin asidero alguno. iSimple broma o pensamiento subterráneo, profundo e insondable? Difícil de dilucidar. Por eso, no deja nunca de ser sugerente el remitirse al comportamiento del diálogo establecido por los actuantes de estas dos novelas, que constituyen un excelente díptico; a raíz de él pueden descifrarse los extraños avatares de una literatura, en efecto, profunda, discordante y muy complicada de ordenar.

Sin embargo, o quizá por eso mismo, el personaje arltiano siempre ha despertado un interés particular en el lector contemporáneo, pese a que su comportamiento regularmente ha sido etiquetado con el apelativo de poseer un perfil esquizofrénico, visiblemente detectable a partir de la distribución dialógica con la que el autor establece la afluencia de ideas entre los protagonistas que desfilan por sus obras. Desde luego, resulta comprensible que en una primera aproximación a la lectura, la disociación de ideas, la corrupción de ideologías y la angustia que rige el modus operandi de los diálogos hagan saltar las alarmas, y tras éstas la duda, el morbo y la perplejidad. Pero ya fuera por una u otras causas, la lectura de estos textos siempre ha estimulado una poderosa sensación de incierta curiosidad.

Pero este díptico también tiene la virtud de robustecer una extraña certeza, que se va estableciendo desde la prematura lectura de las primeras páginas, y que puede quedar resumida con estas breves palabras: "aquí algo no anda bien".

1 Roberto Arlt, Los siete locos, pról., ed. y notas de Flora Guzmán, 2ª ed., Madrid, Cátedra, 1997 (Letras Hispánicas, 353); y Los lanzallamas, 4a ed., Buenos Aires, Losada, 1997. Utilizo, para las citas de los textos, las siguientes abreviaturas: para Los siete locos (Sl) y para Los lanzallamas (Ll). 
Valor complejo, que deja al espectador parado ante el texto con un enorme y frondoso "palmo de narices".

Como toda literatura, las obras de Roberto Arlt han sido sometidas a diversas secuencias interpretativas, análisis, estudios y observaciones que generaron, en sus inicios, notables detracciones en los ambientes literarios argentinos, pero que con el tiempo se fueron convirtiendo en singulares distinciones, según fue cambiando la orientación de la lectura. Esto es, sin duda alguna, un evento inevitable del proceso de juzgar, compartir o rechazar toda obra literaria.

Y es que en Los siete locos y Los lanzallamas Roberto Arlt nos seduce con un complejo diálogo, que con el tiempo ha causado extrañas impresiones en el público lector y en la crítica literaria en particular. Diálogo profundo y extenso que en ocasiones florece vacío, falto de toda concatenación lógica, lleno de angustia, sufrimiento, eventos trágicos, pensamientos descontrolados, soluciones atroces y eventuales que, a final de cuentas, no solucionan nada. iEse diálogo no es un diálogo, es un monólogo!, ha exclamado con toda justicia Horacio González, ${ }^{2}$ y no le falta razón.

En el extenso diálogo arltiano no existe el conversar, el discutir, por lo menos no en la forma como el pensamiento griego heredó al pensamiento contemporáneo. La conversación arltiana no formula preguntas, emite o irradia exabruptos; asimismo nunca manifiesta u ostenta respuestas, porque en ningún momento parece buscarlas. Es un constante fluir en una perorata al vacío, en un diálogo/monólogo entre sordos o, mejor aún, en un diálogo/monólogo entre locos, como bien lo expresa el título a la primera de las obras que constituyen el díptico; este diálogo furioso, bestial, continúa distorsionándose con una progresión sorprendente durante la segunda parte, que bien pudo haber sido titulada Los monstruos, como inicialmente tenía estimado Arlt. Pero entendámonos, porque hablar de locura en la literatura no es lo mismo que hablar de locura en la medicina, la psiquiatría o el psicoanálisis. No es lo mismo un loco de manico-

2 Horacio González, Arlt. Política y locura, Buenos Aires, Colihue, Puñaladas, Ensayos de Punta, 1996. 
mio (que debe someterse a un diagnóstico clínico) a un personaje de novela (que requiere de un diagnóstico interpretativo).

Si bien la obra de Arlt es extensa: novela, cuento, teatro, artículos periodísticos y un difuso ensayo con el que inicia su carrera literaria (Las ciencias ocultas en la ciudad de Buenos Aires, de 1920), no deja de ser sorprendente la distancia que media entre unos y otros textos, que a veces dejan la impresión de estar escritos por diferentes personas. En el caso de Arlt, parece notable que la fortaleza (y curiosamente madurez) de su discurso se encuentra arraigado en su segunda y tercera novela, cuando contaba apenas con 29 y 31 años de edad, respectivamente; sus demás textos, como bien señalará Julio Cortázar, son "la paradoja de una escritura prácticamente libre de defectos formales pero al servicio de mediocres cuentos exóticos, nacidos de un tardío y deslumbrado conocimiento de otras regiones del mundo, y que salvo alguno que otro pasaje carecen de esa atmósfera que es el estilo profundo de su mejor obra". ${ }^{3}$

En efecto, tras Los siete locos y Los lanzallamas, la prosa arltiana y su vasta producción teatral carecen del ímpetu y la luminosidad que identificó a su literatura inaugural; lo que resulta curioso, ya que fueron sus obras preliminares las que cultivaron mayores reticencias por parte de los círculos intelectuales bonaerenses, pese a ser las más logradas. No en vano Arlt se quejó siempre de la incomprensión a la que fueron sometidos sus primeros escritos, en las tan comentadas "Palabras del autor", texto que precede la inauguración de Los lanzallamas, señala: "Se dice de mí que escribo mal. Es posible. De cualquier manera, no tendría dificultad en citar a numerosa gente que escribe bien y a quienes únicamente leen correctos miembros de su familia" ( $L l$, p. 7).

La actitud de Arlt al defender sus procesos narrativos siempre fue parcial y muy mal argumentada (réplicas que mostraron, ante todo, la animadversión que sentía contra los círculos literarios que lo segregaban); pero también exteriorizaba el apremio del autor por formarse un temperamento único, propio. Edificación que había iniciado en 1926 con la aparición de El juguete rabioso, primera novela de Arlt, y que con Los siete locos y Los lanzallamas alcanzará su

3 Julio Cortázar, "Prólogo", en Roberto Arlt, Obra completa, 3 ts., Buenos Aires, Planeta-Carlos Lohle-Biblioteca del Sur, 1991, t. III, pp. vI-VII. 
mayor amplitud. Arlt siempre fue consciente de ello y la falta de reconocimiento al que se creía merecedor ejerció sobre él una fuerza devastadora, fuerza que sin embargo, más que amedrentarlo, lo ayudó a reforzar y consolidar los sistemas de escritura del díptico que es objeto de este escrito.

Pero volvamos a la idea del diálogo en Arlt. Porque un escritor no es siempre el mismo escritor... multifacético, disforme, multidisciplinario, el poeta se transforma a sí mismo en su propio diálogo/monólogo, mientras va legando a sus lectores una profunda y paradójica visión de su quehacer crítico, porque la literatura, a final de cuentas, también se somete al proceso de juzgar, evaluar o valorar. El ejercicio de la creación es un diálogo inconcluso entre el autor y el texto, entre el texto y el lector y, por consiguiente, entre el lector y el escritor. Desde luego, también es un diálogo entre generaciones, ideologías y culturas disímiles; y a este intercambio dialógico Mijaíl M. Bajtín lo definía como la polifonía de los discursos literarios.

Diálogo polifónico, porque incluye variedad de escenarios, interacción de conciencias, ideas desiguales, pluralidad de sentidos, en resumidas cuentas, lo que Bajtín llama "cruces dialógicos", con los que se crea y recrea la novela polifónica en el "diálogo universal". Diálogo que en Roberto Arlt podría argumentarse, se encuentra constantemente torcido, roto, principalmente en sus contenidos ideológicos, pero que a su vez dirige magistralmente los sistemas de comunicación de toda su estructura narrativa, como puede quedar ejemplificado en el siguiente párrafo de Los lanzallamas:

-iUstedes quieren paz!... iUstedes quieren evolución!... Es absurdo todo lo que pretenden ustedes... mezcla infusa de socialistas, demócratas, etc., etc. ¿Y sabe usted cuáles son los revolucionarios más tremendos que hoy pisan el suelo de la humanidad? Los capitalistas. Una mujer puede fabricar un hijo en nueve meses; un capitalista puede fabricar mil máquinas en nueve meses... Mil máquinas que dejan en la calle a mil hijos de mujeres que tardaron nueve mil meses en concebirlos. Y yo quiero la revolución. Pero no una revolución de opereta. La otra revolución. La revolución que se compone de fusilamientos, violaciones de mujeres en las calles por las turbas enfurecidas, saqueos, hambre, terror. Una revolución

4 Mijaíl M. Bajtín, Problemas de la poética de Dostoievski, trad. de Tatiana Bubnova, Madrid, FCE, 2004 (Breviarios, 417). 
con una silla eléctrica en cada esquina. El exterminio total, completo, absoluto, de todos aquellos individuos que defendieron la casta capitalista ( $L l$, p. 95$)$.

Y es que el diálogo en Arlt siempre se da con un espontáneo rechinar de dientes, lo que posiblemente haga insólito su procedimiento y lo que, a su vez, plantea un desafío a su subsiguiente interpretación; porque ahí, en ese diálogo crispado y furioso se encuentra la afirmación de su propuesta ideológica, y no la negación, como muchas veces se ha querido ver. Arlt no dialoga para entablar acuerdos y mucho menos para establecer principios; sólo reconstruye los mecanismos con los cuales fueron bosquejados los límites cartográficos del mapa ideológico de su época y, a través de esta comprensión, aprende a conversar consigo mismo, aprende a conspirar contra una cultura a la que pertenece, pero que ve diezmada por sus propios mitos, siempre hechizados por la quimera de la civilización y el progreso que se esgrimía desde algunos sectores de Occidente. Espíritu curioso y rebelde, consciente de habitar en un mundo desequilibrado y doliente, que sin embargo se exhibe como mesiánico y purificador, Arlt arroja a sus personajes a transitar por los callejones que el pensamiento y la cultura occidental han trazado como límites de sus propias urbes descarnadas. Y eso nos muestra a cada momento la voz narrativa; todo en ella está cimbrado, lo que no quiere decir que esta crispación le haga perder su densidad expresiva o su calidad de precisión, donde Arlt va agrupando de manera aleatoria y desordenada todos los elementos que sostienen su quehacer crítico.

Muchas veces se ha dicho que la literatura arltiana tiene algo de autobiográfica... Es posible, si por autobiográfica comprendemos también sociobiográfica, culturobiográfica. Arlt tejió, en efecto, su ideales artísticos en torno a un discurso embravecido, motivado por algunas corrientes literarias y filosóficas de su tiempo; piénsese en la influencia que pudieron ejercer en el imaginario arltiano las literaturas de vanguardia de los años veinte, el existencialismo o el decadentismo, todas ellas sacudidas por la sensación de estar viviendo en una cultura en crisis (el pensamiento de Nietzsche, desde luego, también asoma entre bambalinas). Arlt personifica cabalmente ciertos pronósticos intelectuales que desde la Europa occidental hacían eco profundo en los contextos socioculturales de 
Latinoamérica. Estas ideas de decadencia, crisis y ruptura siempre fueron parte de su actividad creadora, actividad de la que Arlt era muy consciente.

Aunque sería complicado delimitar hasta qué punto las ideas de su mundo circundante fueron un proyecto deliberadamente meditado por el autor, no cabe duda que Arlt, con sus escritos, estaba reflejando la fuerte inestabilidad intelectual de la época, no nada más la política o social sino, ante todo, la intelectual. Pero, ihasta dónde Arlt comprendía estas doctrinas? Y, más aún ¿era consciente de la fortaleza crítica que alcanzaba con la expresión de sus ideas?

Dentro del marco general de la interpretación de los textos, se ha estimado con frecuencia que Arlt fue un autor que poseía una poderosa intuición sobre los procesos políticos que contemplaba en su contexto, y no es de extrañar, pues siempre está presente en él la proximidad existente entre la ideología que ostenta la sociedad secreta con su referencialidad histórica, pese a la complejidad y distorsión que impera dentro de sus diálogos.

Jorge Rivera, al respecto, ha señalado que los fantasiosos proyectos de la sociedad secreta no hacen sino reproducir y respaldarse en "[... la crisis del racionalismo y en los progresos correlativos de la corriente 'irracionalista' y de otros fenómenos concomitantes". ${ }^{5}$ Influencia que convertiría a Arlt en un autor malicioso y crítico y, a su vez, otorgaría a su literatura una fuerza significativa, que invita al lector una y otra vez a reflexionar sobre el pesimismo que se encuentra inmerso en las páginas de estos textos, ya sea contenido en la ideología que ostenta la organización revolucionaria, comandada por el Astrólogo, ya por vía

5 "Pensemos - continúa Rivera - en el mito revolucionario que sustenta la sociedad secreta y alimenta, de paso, los discursos mesiánicos del Astrólogo. Entre 1917 y 1926 se han producido en Occidente la insurrección de Irlanda, la revolución bolchevique, la revolución espartaquista alemana, la sublevación de von Kapp, Vela Kun en Hungría, la marcha fascista sobre Roma, la dictadura de Primo de Rivera en España, el putsch nazi de Munich, el golpe de Estado de Pilsudski y Polonia y la dictadura de Salazar en Portugal. Derechas e izquierdas se han disputado encarnizadamente el poder, y puede decirse que el imaginario político colectivo está saturado por las imágenes apocalípticas o redentoristas del golpe de Estado [...]. Lo curioso, en esta atmósfera, es no ceder frente a las seducciones de la utopía revolucionaria, cualquiera fuere su signo, y en ese preciso sentido la imaginería y los discursos 'ideológicos' de Los siete locos - dentro de su veracidad referencial- son menos 'anticipatorios' que 'residuales". Jorge B. Rivera, Roberto Arlt, Los siete locos, Buenos Aires, Hachette, s/f, pp. 45 y 46. 
de la conciencia fracturada del protagonista principal, Augusto Remo Erdosain, y que Arlt, con su estilo característico, llevó a la literatura argentina no sin cierto extrañamiento, que aún ahora sigue produciendo un giro vertiginoso en sus lectores y la crítica literaria en general.

Y es que el pesimismo cínico con el que Arlt plantea su discurso narrativo hace "imposible - como sugiere Rose Corral6 - unificar en una mirada coherente y verosímil la propuesta revolucionaria del Astrólogo". Coherencia que, a la hora de analizar los textos, se le ha echado en falta y ha suscitado una larga controversia sobre sus contenidos. A causa de esta transición discursiva y las múltiples tensiones que genera, la crítica ha desestimado con frecuencia la orientación de sus afirmaciones (aunque no niega las curiosas correspondencias existentes con la ideología y los sucesos políticos de su entorno), al parecer más destinadas a entorpecer o enrarecer la comunicación, que a descifrar eventos manifiestos de su referencialidad histórica, lo cual, naturalmente, no era su objetivo.

Por ello, rastrear hasta qué punto las ideologías de la época lograron penetrar en el imaginario arltiano no es tarea sencilla, aunque no cabe duda que el tópico de la tecnología, el progreso, la degeneración o la decadencia, provenientes de algunos ambientes europeos decimonónicos, se habían filtrado ya en las arterias de estos escritos. Estas significaciones reaparecen insertadas en la narrativa arltiana una y otra vez, y se hacen ampliamente entendibles cuando uno vuelve la mirada a la idea de decadencia, según la concebía una parte de la filosofía y la cultura europea heredada del siglo xIx, y que a través de textos de autores como Charles Baudelaire, F. M. Dostoievski o Friedrich Nietzsche, de los que Arlt era asiduo lector, llegaron a las páginas de este díptico.

Y en efecto, más que ninguna otra, la idea de decadencia parece estimular poderosamente la visión pertinente y audaz de Los siete locos y Los lanzallamas.

En La idea de decadencia en la historia de Occidente ${ }^{7}$ Arthur Herman postula, en términos generales, una serie de tópicos que define la transición del

6 Rose Corral, "La sociedad secreta y la rebelión de los magos: una aproximación a Los siete locos y Los lanzallamas", en Nueva Revista de Filología, vol. 36, núm. 2, México, 1988, p. 1267.

7 Arthur Herman, La idea de decadencia en la historia de Occidente, trad. de Carlos Gardini, Barcelona, Andrés Bello, 1997. 
mundo moderno al posmoderno, a través de la idea que sobre la decadencia fue formándose en el seno del pensamiento del siglo xIx y terminó por convertirse "en lo que quizá sea el tema más dominante e influyente de la cultura y la política del siglo veinte. No sólo ha afectado la vida de la gente de modos inesperados y sorprendentes $[\ldots]$, sino que quizá sea inseparable de la idea misma de civilización".

El hombre iluminista había hecho uso de la ciencia y las artes mecánicas como expresión de su armonía con la naturaleza, entendida como ley natural. El iluminismo francés creía que los procesos industriales y tecnológicos constituían expresiones saludables del progreso de la sociedad civil. Estas ideas se vieron radicalmente transformadas cuando los románticos hicieron su aparición en escena, al rechazar la naturaleza como orden legal racional.

Herman entiende que esta ruptura involucraría con el tiempo dos tradiciones diferentes: el pesimismo histórico y el pesimismo cultural, porque por "cada intelectual occidental que teme el colapso de su sociedad [...], hay otro que aguarda ese acontecimiento con delectación".?

En ambos casos, y como crítica de la sociedad industrial del siglo xIx, el decadentismo asumía que la sociedad moderna estaba en una fase de crisis espiritual. Codicioso y materialista, sin noción de los valores humanos, el individuo se convertía en rehén del desequilibrio psicológico, el aislamiento y el desarraigo.

Pero será el pesimismo cultural el que represente la visión más oscura y radical de la idea de decadencia, ya que:

Encarna una visión específica de la historia moderna, ejemplificada por el título de la sombría obra maestra de Oswald Spengler, La decadencia de Occidente. El mundo moderno y el hombre moderno, afirma el pesimista cultural, están atrapados en un proceso de deterioro, agotamiento y colapso inevitable. El pesimismo cultural está muy influido por la filosofía de Friedrich Nietzsche y su condena general de la sociedad europea de su época como "enferma" y "decadente" $[\ldots]^{10}$

8 Ibid., pp. 16 y 17.

9 Ibid., p. 17.

${ }^{10}$ Y continúa: "En su contexto europeo original, el pesimismo cultural abarca todo el espectro político e ideológico. Marcuse era marxista, Heidegger recibió a Hitler con entusiasmo, Oswald Spengler con reservas. Nietzsche, por su parte, despreciaba las etiquetas políticas convencio- 
Como motores de una tradición de ruptura y crisis, estas dos actitudes intelectuales (el pesimismo histórico y su antítesis, el pesimismo cultural), representarán, por inversión, las ideas de progreso y decadencia. Mientras los primeros sostenían que fuerzas oscuras y autodestructivas quebrantaban las virtudes de la civilización, los segundos afirmaban que esas fuerzas constituían el proceso civilizador desde el comienzo. El pesimista histórico señala que la sociedad está autodestruyéndose, el pesimista cultural sostiene que merece ser destruida. "El pesimista histórico ve 'el desastre en la estrella polar', como Henry Adams: el pesimista cultural ansía el desastre, pues cree que algo mejor surgirá de las cenizas."

La idea de decadencia hacía estragos en todos los horizontes culturales e intelectuales de la Europa industrial: el progreso abandonaba su significado original de avance económico y político y hacía patente, a mediados del siglo XIX, que la tecnología y el industrialismo ya no parecían ser instrumentos útiles para brindar una sociedad estable y segura, sino todo lo contrario. La clase intelectual presagiaba que la civilización había arribado a tal grado de progreso que "como diría Spengler en El bombre y la técnica, 'la civilización misma se ha convertido en máquina'. Las vigorosas imágenes de la película Metrópolis, de Fritz Lang, donde los seres humanos son simbólicamente sacrificados a una máquina industrial, reflejaba el temor de que la tecnología controlara a sus usuarios". ${ }^{12}$

Al iniciar el siglo xx los presagios sobre la degradación de la cultura y el espíritu occidental, a manos del capitalismo y la tecnología, estaban tan arraigados que habían ensanchado sus fronteras a todos los males de las sociedades modernas; ahora el crimen, la locura, el suicidio, el alcoholismo o la neurosis también parecían ser producto de la degeneración fisiológica, engendrada por la era tecnológica e industrial de la modernidad y sus grandes urbes. El inicio de la Primera Guerra Mundial no hará sino aumentar esos ecos de crisis e inestabilidad.

nales. El pesimismo cultural es un ataque contra la cultura occidental moderna que antecede y trasciende la adhesión al credo marxista o socialista [... . Al margen del país, la época y la orientación política, todos los autores comparten la misma visión profética: la civilización burguesa capitalista de sus tiempos, fuera 1846 o 1886, 1946 o 1996, está condenada a la autodestrucción", en ibid., pp. 17 y 18.

${ }^{11}$ Ibid., p. 442.

${ }^{12}$ Ibid., p. 233. 
En Argentina, si bien no existía un debate propiamente sobre estas nociones, el auge migratorio había traído consigo las ideas políticas y sociales de Europa, socialistas y anarquistas harán así su aparición en escena, originando una convulsión social de grandes dimensiones ante los evidentes síntomas de miseria, explotación y desempleo, que poco a poco iban mermando la sensación de riqueza y modernidad que esgrimía el país a principios de siglo. Arlt comenzará la escritura de Los siete locos justo cuando las turbulencias políticas y sociales se hacían más y más inestables, y que terminarían por culminar con el golpe de Estado de 1931 al gobierno democrático de Hipólito Irigoyen.

Estos evidentes síntomas de malestar parecen motivar la sociedad secreta del Astrólogo, aunque no reducidos a sus significaciones más palpables, la pobreza y la explotación obrera o campesina (más propias de la estética literaria del grupo de Boedo), sino a sus significaciones más oscuras, la degeneración social en casi todos sus niveles.

Como bien lo ha señalado Rose Corral, la sociedad secreta parece "perseguir un doble objetivo: por una parte, la desaparición o, mejor dicho, la destrucción ciega, apocalíptica de la sociedad de explotación capitalista y, por otra, el restablecimiento de la fe perdida $[\ldots]$, condición necesaria para sanar el alma enferma del hombre contemporáneo". 13

Arlt había hecho suyos los oscuros presagios que el pesimismo decimonónico esgrimía para las sociedades modernas del siglo xx, y no resulta factible que esta asimilación haya sido una mera casualidad producida indirectamente por las lecturas europeas de Arlt, en la primera parte de Los siete locos, el Astrólogo le dice a Erdosain: "Yo leo mucho, y créame, en todos los libros europeos encuentro este fondo de amargura y de angustia que me cuenta de su vida de usted" (Sl, p. 161).

El análisis arltiano sobre la moderna sociedad argentina no pudo excluir los procesos de transición que las corrientes pesimistas habían vaticinado algunas décadas antes para las sociedades occidentales. La deshumanización, el crecimiento incipiente y descontrolado de las urbes, la falta de valores, la angustia que imperaba en una ciudad como Buenos Aires (a la que Erdosain llama la "ciudad

${ }^{13}$ Corral, op. cit., p. 1268. 
canalla"), que poco a poco era presa de la segregación, ayudaron a Arlt a representar su imaginario social: "Completamente, y créame... seremos cuando menos los dueños del país... si no del mundo. Tenemos que serlo. Lo que proyecta el Astrólogo es la salvación del alma de los hombres agotados por la mecanización de nuestra civilización" (Sl, p. 238), le dice el Buscador de Oro a Erdosain. También Hipólita y el Astrólogo dialogan: “-Sí, nada más que recuerdos es la vida... / - Yo quiero que sea futuro. Futuro en campo verde no en ciudad de ladrillo" ( $L l$, p. 26).

Arlt creía, como algunos de sus contemporáneos, que los procesos civilizadores, dentro del sistema de "explotación capitalista", hacían eco profundo en el comportamiento y el desarrollo de las sociedades, muestra de ello es la constante recriminación que realiza por medio de sus páginas periodísticas contra su entorno polííico, económico, social y cultural. Sin embargo, en Los siete locos y Los lanzallamas, estos asaltos y murmuraciones razonables se convierten en alaridos salvajes de desesperación, angustia y distorsión de los procesos políticos y sociales que observaba. Distorsión que, dentro de nuestra referencialidad histórica contemporánea, resultan meras curiosidades literarias, pero que en la década de 1920 no eran del todo exageradas.

La posición reformista con la que los intelectuales europeos proponían el resurgimiento de sus civilizaciones (y que indirectamente causarían más tarde la aparición del nacionalsocialismo de Hitler o el fascismo de Mussolini), es perfectamente afín a la ideología que proyectaba el Astrólogo.

Herman menciona que cuando Spengler publicó en 1920 (nueve años antes de la aparición de Los siete locos) su Prusianismo y socialismo (apología de la revolución derechista alemana), se estaba operando un extraño cambio de dirección en la ideología europea, particularmente en la de Alemania, pues Spengler intentaba arrebatarle el socialismo a los marxistas. La derecha alemana, como los marxistas, comenzaba a apelar a las clases obreras para enfrentar lo que consideraban los peligrosos intereses capitalistas de Occidente. Vocablos como "dictadura", "organización", "élite", "Estado" y mensajes de unión entre obreros, intelectuales y soldados, eran componentes sugerentes de todos los discursos políticos e intelectuales de la época. 
También el filósofo español Ortega y Gasset, que tuviera fuerte influencia en las jóvenes generaciones argentinas con las dos visitas que realizó a Buenos Aires, la primera en 1916 y la segunda en 1928, había afirmado: "Hoy las derechas proponen revoluciones y las izquierdas tiranías." ${ }^{14}$ Si bien buena parte de la crítica arltiana se da en los evidentes síntomas de la desesperación y la angustia, los sueños omnipotentes y las alucinaciones, condensados en una extraña amalgama de ideologías que enredan al lector y ensombrecen la fuerte y hábil sátira con la que el Astrólogo pretende redimir a la humanidad, ${ }^{15}$ y que parecen, en los límites de la invención, producto de una imaginación fantástica o, en última instancia, desquiciada, en el plano de la ficción se transforman en sugestivas y poderosas afirmaciones, que emulan las alucinaciones enunciativas de los discursos políticos de la primera mitad del siglo xx.

La guerra (como principio vital y creador) ${ }^{16}$ el superhombre de Nietzsche, el totalitarismo de Estado, ${ }^{17}$ también cimentaba las nuevas esperanzas de las so-

${ }^{14}$ José Ortega y Gasset, La rebelión de las masas, introd. de Julián Marías, Barcelona, Planeta (Obras Maestras del Milenio, 7), p. 60.

15 Ejemplarmente expresadas en afirmaciones como la siguiente: "Mi sociedad está inspirada en aquella que a principios del siglo noveno organizó un bandido llamado Abdala-Aben-Maimum [...]. Maimum quiso fusionar a los librepensadores, aristócratas y creyentes de dos razas tan distintas como la persa y la árabe [...]. De esta manera Maimum esperaba llegar a dominar por completo al mundo musulmán. Excuso decirle que los directores del movimiento eran unos cínicos estupendos, que no creían absolutamente en nada. Nosotros les imitaremos. Seremos bolcheviques, católicos, fascistas, ateos, militaristas, en diversos grados de iniciación" (Sl, p. 214).

${ }^{16}$ Herman menciona que "entre los jóvenes vanguardistas, las portaestandartes del modernismo, la guerra sólo cimentó la fascinación por lo irracional y lo violento como opuestos vitales de la vida civilizada. Tanto nietzscheanos como los no nietzscheanos alababan la propensión del hombre a matar y a agredir como partes importantes de la experiencia [... ]. La violencia agresiva fascinaba a autores ingleses como D. H. Lawrence y Wyndham Lewis, mientras en Alemania intelectuales de izquierda (como Bertolt Brecht) y de derecha (como Oswald Spengler) exploraban sus posibilidades creativas. Alexandre Kojéve enfatizaba la necesidad del derramamiento de sangre y la revuelta en el proceso histórico, no como parte de la lucha darwiniana por la supervivencia sino como parte de la naturaleza vital del hombre. La historia, proclamaba Kojéve (en forma similar a Bergson), era un campo de acción y no de contemplación, otro motivo por el cual el ascenso de una burguesía lánguida y complaciente marcaba el fin de la historia". Arthur Herman, op. cit., p. 336.

${ }^{17}$ A las cuales también apela el discurso del Astrólogo frecuentemente, como puede verse en los siguientes diálogos del Astrólogo con Hipólita y el Abogado: “-Lo sé. También sé que el amor 
ciedades modernas, con las cuales se pretendía sortear la degeneración a la que se creía estaba condenada la cultura y las civilizaciones europeas y norteamericana; el modelo de producción capitalista, la democracia, y su producto más relevante, la "corrupta" sociedad burguesa, se convertían en blanco de todas las recriminaciones; todas las voces, derechistas o izquierdistas, aseguraban que algo mejor tendría que suplantar a la descompuesta sociedad de extracción capitalista. El comentarista de la historia de Los siete locos y Los lanzallamas, una herramienta más que Arlt utiliza para darle algunos acentos de verosimilitud a su relato, nos dice sobre la conducta del protagonista: "La puerca civilización lo ha magullado, lo ha roto internamente, y el odio sopla por sus fosas nasales" ( $(\mathrm{Ll}, \mathrm{p} . \mathrm{53}$ ).

Arlt, haciendo uso de los instrumentos que su entorno intelectual, cultural, político y social le ofrecían, transformará su escritura en un laboratorio de apreciaciones estilísticas e intelectuales; dicho diagnóstico, desde luego, no lo obligó a reproducir los códigos dialógicos, tal cual serían contemplados o expresados por ciertas normas filosóficas o políticas, es decir, a través de la verosimilitud. Arlt poseía sus propios códigos comunicativos, más cercanos a las estéticas literarias que circulaban por entonces en los ambientes literarios ("la comedia del absurdo" o "la parodia demente", como define Matei Calinescu ${ }^{18}$ al arte vanguardista) y, por supuesto, fuertemente seducido por la noción de crisis y decadencia, que hacía estragos profundos en los ambientes intelectuales europeos. Arlt no miraba estos procesos con desprecio, pero sí con recelo; tal vez convencido de que la cultura experimentaba un momento de crisis espiritual, deterioro y agotamiento (como le asegura el Buscador de Oro a Erdosain en Los siete locos: "Las ciudades son los cánceres del mundo. Aniquilan al hombre; lo moldean cobarde, astuto, envidioso, y es la envidia la que afirma sus derechos sociales, la envidia y la cobardía" (Sl, p. 240); creará una escritura que se expresará a través de múltiples planos in-

salvará a los hombres; pero no a estos hombres nuestros. Ahora hay que predicar el odio y el exterminio, la disolución y la violencia" ( $L l$, p. 25); "¿Qué significa entonces el peligro de una dictadura militar, si esta dictadura puede provocar el resurgimiento de una fuerza colectiva destinada a terminar de una vez por todas con esa criminal realidad del capitalismo?" ( $L l$, p. 85).

${ }_{18}$ Matei Calinescu, Las cinco caras de la modernidad. Modernismo, vanguardia, decadencia, kitsch, posmodernismo, trad. de María Teresa Berguirstain, Madrid, Tecnos, 1987 (Col. Argumento, 115). 
conexos, donde la ideología y la comunicación, que debería ser el vehículo que transmitiera esta ideología, quedan gravitando cómicamente en los límites de la distorsión y la incomprensión; Arlt replantea de este modo la visión de un imaginario social que no terminaba por definir sus nuevas formas, que desconocía los límites hasta donde se ensanchaban sus fronteras.

Es cierto que en Arlt los diálogos parecen no tener ni pies ni cabeza, pero esto es perfectamente comprensible si concebimos que en un mundo distorsionado y fragmentario es imposible imaginarse a un hombre unificado. Jean Baudrillard, en el epígrafe de su libro La transparencia del mal. Ensayo sobre los fenómenos extremos, ${ }^{19}$ afirma: "ya que el mundo adopta un curso delirante, debemos adoptar sobre él un punto de vista delirante", algo que Arlt comprendía muy bien. Y es, precisamente, el choque de todas estas conciencias distorsionadas, unidas en el diálogo universal, el que genera el nacimiento de la angustia, entendida ésta en su definición más formal, es decir, como la actitud del hombre frente a su situación en el mundo: "Además, un enigma abre su paréntesis caliente en sus entrañas; este enigma es la razón de vivir. Si le hubieran clavado un clavo en la masa del cráneo, más obstinada no podría ser su necesidad de conocer la razón de vivir. Lo horrible es que sus pensamientos no guardan orden sino en escasos momentos, impidiéndole razonar" ( $L l$, p. 51), nos dice en Los lanzallamas el comentarista de esta historia sobre la conducta de Erdosain.

Pero la angustia y el diálogo, aunque parecen incompatibles, no lo son, porque angustiarse es dialogar consigo mismo, sin perder de vista el diálogo universal. Aunque no cabe duda de que Horacio González acierta al afirmar que Arlt desencaja su discurso dialógico, convirtiendo cada frase en un interminable monólogo que desarma "la continuidad operativa del diálogo" ${ }^{20}$ el discurso arltiano también posee otros atributos, que no pueden eludir esa profunda fascinación que caracteriza a toda su literatura: la creación de realidades paralelas, profundamente distorsionadas por la angustia que el autor veía en el comportamiento y la actitud del hombre moderno y su contexto cultural e intelectual.

19 Traducción de Joaquín Jordá, Barcelona, Anagrama, 1997 (Col. Argumento, 115).

${ }^{20}$ González, op. cit., p. 24. 
La misión de Arlt consistió, precisamente, en mezclar estas realidades paralelas en una atmósfera crítica, que es llevada hasta sus últimas consecuencias, tanto en lo ético como en lo estético. La conciencia de la referencialidad a la que nos remite el autor se experimenta en un sentido profundo, arraigada en la enfermiza realidad que nos presenta. Y es el roce con "los otros" lo que saca chispas en la fricción que termina por incendiar cualquier comodidad, porque el diálogo se manifiesta durante todo el relato como un rastro fugaz y confuso de la necesidad de autoafirmación del "yo" ante "la nada" que se le plantea.

Sin embargo, no deja de ser sugerente que este conversar disforme, incómodo, constantemente nos recuerda que de la descripción disparatada, con frecuencia brotará la opinión razonable, la opinión de aquel loco platónico, misterioso, poseedor de una verdad profética, purificadora. Las torsiones dialógicas arltianas sí realizan un verdadero y efectivo cruce dialógico, que en este espacio me gustaría definir -siguiendo a Bajtín - como un "monólogo interior completamente dialogizado". ${ }^{21} \mathrm{Y}$ en esta transición furiosa del diálogo-monólogo-diálogo, es donde Arlt descubre la grandeza de su discurso: angustiarse es dialogar consigo mismo, pero, también, angustiarse es entablar conversación con el diálogo universal, sin importar la modulación o las variaciones de la voz expresiva, que en Arlt, naturalmente, son bestiales. El equilibrio dialógico se logra cuando el lector consigue hacer a un lado la verosimilitud que tanto aqueja a la crítica, para abrir paso a una nueva comprensión de lo real, que queda ejemplarmente expresada por medio de la desesperación y la angustia, que si bien distorsionan el diálogo no lo derogan y, mucho menos, lo proscriben.

Desde luego, estas observaciones no procuran reducir la lectura arltiana a un proceso de comprensión político o doctrinal, si no sólo resaltar las múltiples relaciones existentes entre la literatura y su trasfondo cultural (y las correspondencias necesarias que se establecen entre una y otra), que en este espacio he considerado pertinentes para comprender aspectos relevantes del texto. Como bien explica Ricardo Piglia, cuando uno "dice ideología en la literatura, está hablando de las formas, no se trata de los contenidos directos, ni de las opiniones

${ }^{21}$ Bajtín, op. cit., p. 114. 
políticas". ${ }^{22}$ Y estas formas nos revelan su carácter profético y analítico, cuando el lector comprende cómo todas las voces-ideas de una época dada interactúan simultáneamente en este diálogo multifacético y con derechos iguales (como manifestaba Bajtín); que Arlt, particularmente, lo expresara de forma distorsionada es otro asunto.

Hago esta obvia distinción para resaltar que la verosimilitud de Los siete locos y Los lanzallamas no depende de la verosimilitud histórica; justificar las primeras, por vía de las segundas, naturalmente, sería erróneo, sin embargo, comprender la intertextualidad del diálogo de una obra y su contexto, contribuye a esclarecer las relaciones entre los textos y los escenarios en los que se producen. Al respecto Ana María Zubieta aseguraba:

No hay primer libro, ni libro independiente absolutamente inocente: la novedad, la originalidad en la literatura se define siempre por relaciones. El escritor se apodera de toda la tradición literaria, la hace suya, y saltando sobre las formas y los hombres, hace jugar en el espacio del nuevo texto, citas, trozos, páginas que reactivan y certifican que la literatura es un proceso de trabajo [...]. La intertextualidad quizá sea un diálogo y una contaminación de textos, pero sólo la posición ideológica del que escribe le dará su operatividad real". ${ }^{23}$

Los orígenes de la poética arltiana son sedimentados en lo que aquí definiré como un polifacético alegato de la angustia. Arlt reconstruye, con un estilo particular, un extenso puente dialógico por el cual transita dando tumbos, como si fuera montado en una corveta de doble proa, lo mismo da atrás que adelante, a un lado o al otro. Esta sensación de ruptura y crisis, que se entabla desde la presentación del discurso y, desde luego, dentro de los contenidos ideológicos y dialógicos de las obras, siempre fue defendida por la narrativa arltiana, escritura tan distorsionada por el sentimiento de la angustia y la decadencia, que muy rápidamente fue tachada, en sus inicios, como arengas caracterizadas por enormes vacíos, caóticas, sin secuencia narrativa, pero que ahora constituyen la verdadera

22 Ricardo Piglia, Crítica y ficción, Barcelona, Anagrama, 2001 (Col. Argumentos, 267), p. 82.

${ }^{23}$ Ana María Zubieta, El discurso narrativo arltiano. Intertextualidad, grotesco y utopía, Buenos Aires, Hachette, 1987, pp. 13 y 14. 
fortaleza de una prosa, en efecto, distorsionada, pero también perdurable, genial y paradójica, con la cual Arlt dialogó con los actores de su época, con los lectores de las generaciones venideras, y que ahora se encuentra preparada para entablar un nuevo diálogo, siempre depurado y abierto, con el lector contemporáneo, donde la distorsión y la fragmentación del Ser, se han convertido en la unificación y la razón de la cultura.

Recibido: 10 de enero, 2010. Aceptado: 18 de febrero, 2010. 